\title{
The Impact of Job Satisfaction in the Relationships between Workplace Politics and Work Related Outcomes and Attitudes: Evidence from Organizations in Senegal
}

\author{
Koumakh Faye ${ }^{1} \&$ Ye Long ${ }^{1}$ \\ ${ }^{1}$ School of Economics and Management, Beijing Jiaotong University, China \\ Correspondence: Koumakh Faye, School of Economics and Management, Beijing Jiaotong University, Beijing, \\ Xizhimenwai 100044, China. E-mail: koumakhfaye@gmail.com
}

Received: December 2, 2013

Accepted: April 8, $2014 \quad$ Online Published: April 18, 2014

doi:10.5539/ijbm.v9n5p160

URL: http://dx.doi.org/10.5539/ijbm.v9n5p160

\begin{abstract}
Workplace politics is an endemic factor in organizations. It becomes necessary to look at factors which reduce its negative effects on employees' work outcomes and attitudes. From a sample of 125 individuals working in diverse organizations in Senegal, the findings from multiple hierarchical regressions revealed that workplace politics had less negative effect on organizational commitment, organizational citizenship behavior and job performance when employees are satisfied. The findings also showed that job satisfaction had no influence on the relationship between workplace politics and neglect.
\end{abstract}

Keyword: workplace politics, job satisfaction, work outcomes, work attitudes, Senegal

\section{Introduction and Background}

Politics in the workplace has been defined as 'the maximization of short or long-term interests through strategic planning to seek self-interests by sacrificing that of others' (Yen, Chen, \& Yen, 2009); as actions 'that are self-serving, undesirable and illegitimate' (Miller, Byrne, Rutherford, \& Hansen, 2009) and as actions taken 'without regard for, and even at the expense of organizational goals' (Valle \& Witt, 2001).

The endemic nature of workplace politics (WP) has been largely recognized and discussed by researchers (Buchanan, 2008; Ferris \& Hochwarter, 2011). But studies on WP have been largely directed to employees' reactions to the phenomena (Gbadamosi \& Chinaka, 2011; Karatepe, Babakus, \& Yavas, 2012). While doing this, researchers have put little considerations on or have neglected factors that can reduce the effects of WP on employees work outcomes and attitudes.

It is widely supported in organizational psychology and empirical studies that job satisfaction represents an important variable in predicting employees' work outcomes, behaviors or attitudes (Kaya, 1995; Hirschman, 1970; Rosse \& Saturay, 2004). Our study considers job satisfaction a pivotal factor which will help employees endure political environment. Therefore, the study aims at investigating the arbitrating role of job satisfaction in the relationships between WP and organizational citizenship behavior (OCB), organizational commitment (OC), job performance, and negligent behavior.

\section{Literature Review}

\subsection{Workplace Politics and Employees Work Outcomes and Attitudes}

In recent year, a particular interest has been the effects WP has on employees' job outcomes and attitudes. Employees reacting to perceived WP may have higher intentions to quit, higher job stress and organizational deviance (Haq, 2011); less workplace friendship (Yen et al., 2009) and less pay satisfaction (Harris \& Harris, 2007). They may react through absenteeism (withdrawal), low job involvement, job anxiety (Valle \& Perrewé, 2000), or low job satisfaction (Frost, 1987).

A meta-analysis (Miller, Rutherford, \& Kolodinsky, 2008) indicated strong relationships between WP and both job satisfaction and OC. Vigoda (2000) supported that employees working in politicized workplace reported lower performance. Less affective commitment and OCB were found to be associated with WP (Randall, Cropanzano, Bormann, \& Birjulin., 1999). Employees who perceived politics were also found not to be loyal to their organization; to believe that their organization does not value higher work standards, challenging work, and 
integrity; that their organization does not support innovation (Parker, Dipboye, \& Jackson, 1995).

\subsection{Job Satisfaction and Employees Work Outcomes and Attitudes}

Job satisfaction refers to the general attitude an individual has toward his or her job (Robbins, 2001). Robbins (2000) added that employees satisfied with their job display positive attitude toward their job.

Many claims have been made about the benefits of job satisfactions on employees' behavioral intentions (Cronin, Brady, \& Hult, 2000). Job satisfaction seen as an independant variable has been correlated with many employees' work outcomes or attitudes. More specifically, satisfied employees are said to show positive behaviors or attitudes including increased OCB (Podsakoff, MacKenzie, Paine, \& Bachrach, 2000), higher OC (Meyer, Stanley, Herscovitch, \& Topolnytsky, 2002), increased job performance (Dizgah, Chegini, \& Bisokhan, 2012) or less negligent behavior (Farrell \& Rusbult, 1992).

\subsection{The Mediating Role of Job Satisfaction}

Contrarily to the mainly focus on the systematic importance of job satisfaction on employees's work outcomes and attitudes, little consideration has been made on how job satisfaction helps an employee endure WP. WP is seen as a work stressor that can threaten employees' resources or expected gain (Kacmar \& Carlson, 1997) and negatively affect employees work outcomes and attitudes. WP can be considered a challenge-stressor. Podsakoff, LePine and LePine (2007) reported that challenge stressors have positive effect on job satisfaction and employees' outcomes and attitudes.

Job satisfaction as an intervening variable in the relationships between WP and employees's work outcomes or attittudes has been little discussed. Vigoda (2000) made a short assertion on the issue. By focusing on studies of Baron and Kenny (1986) and James and Brett (1984), Vigoda stated that job satisfaction and OC mediated the relationship between organizational politics and work outcomes such as intentions of exit and neglect and call for further examination.

The scarcity of studies that can help us formalize the role of job satisfaction in the relationship between WP and employees work outcomes or attitudes calls for an urgent need to conduct more research on this topic. Theories and empirical evidences have supported employees' work outcomes, behaviors or attitudes are results of their work or job satisfaction (Hirschman, 1970; Rosse \& Saturay, 2004) and that employees satisfied with their job may overlook or pay less attention to work stressors such as politics. Job satisfaction may help employees endure, overlook or pay little consideration to the political environment. So, we suggest that: Job satisfaction will lessen the effects of WP on employees' $O C B, O C$, job performance, and neglect.

\section{Research Methods}

\subsection{Participants, Procedure and Design}

Participants were employees from public and private organizations located in Dakar, Senegal's capital, West Africa. Participants were assured that their personal information would be secured, strictly confidential, and not be exposed to the public including their managers, supervisors, competitors or any other third party. Out of the 680 prospective participants, 125 provided usable questionnaires. Of the 125 returned valid questionnaires, 124 of the respondents were Senegalese and 1 was Congolese. We found that $16.7 \%$ did not report their gender, $28 \%$ of the respondents were female and 55.3\% male; among them $79.2 \%$ were between 15 and 47 years old.

\subsection{Measures}

\subsubsection{Workplace Politics}

WP was measured using 12 items from the Perception of Organizational Politics Scale (POPS) developed by Kacmar and Carlson (1997) measuring the extent to which employees see their workplace as political. Their POPS has received widespread acceptance (Ferris et al., 2005; Rosen, Levy, \& Hall, 2006). Sample items include (1) 'People in this organization attempt to build themselves up by tearing others', (3) 'Agreeing with powerful others is the best alternative in this organization'. Respondents were asked to report how much they agree with all 12 items. The items were measured on a five-point Likert scale ranging from 1 (strongly disagree) to 5 (strongly agree), so that a higher score corresponds to higher perceptions of workplace politics. Using SPSS 17.0 , the reliability estimate for the scale $(\alpha=.792)$ was acceptable and slightly higher than 0.71 reported in Haq (2011).

\subsubsection{Job Satisfaction}

This variable was assessed using the six items scale borrowed from Schriesheim and Tsui (1980). This scale was found to be reliable in Vigoda and Cohen (2002). The scale contains such items as: 'How satisfied are you with 
your current job?' and 'How satisfied are you with your current salary?' Employees were asked in a five-point Likert format to indicate how satisfied they were with six aspects of their job. The scale ranged from 1 (very unsatisfied) to 5 (very satisfied), with high score indicating high level of satisfaction. The Alpha reliability for this scale was 0.889 .

\subsubsection{Organizational Commitment}

$\mathrm{OC}$ is viewed as a force that binds an individual to a target (social or non-social) and to a course of action of relevance to that target (Meyer, Becker, \& Van Dick, 2006). We resorted to Allen and Meyer's (1990) 21-items to measure OC. Allen and Meyer's (1990) OC scales have won widespread acceptance and have been used in many studies (Atak \& Erturgutb, 2010; Cheng \& Stockdale, 2001). Among the sample items were questions such as (3) 'I really feel as if this organization's problems are my own', (11) 'It would be very hard for me to leave my organization right now, even if I wanted to'. Respondents were asked in a five-point Likert scale ranging from $1=$ Strongly Disagree to $5=$ Strongly Agree to indicate how much they agree with the items. The Alpha reliability for this scale was 0.818 .

\subsubsection{Neglect}

Neglect has been defined as an alternative whereby the individual stays in the organization but expresses dissatisfaction through unproductive activities or even injurious behaviors (Vigoda, 2000). Neglect was measured using 8 items taken from Leck and Saundrers (1992). Employees were asked to complete the items by indicating how much they agreed with them. The items had five response options ranging from 1 (strongly disagree) to 5 (strongly agree). The scale contains items such as (4) 'I put less effort in my work than I know I can', (6) 'I take more and longer breaks than I should'. The reliability for this scale was 0.776 , a bit higher than Vigoda (2000)'s findings and that of Farrell and Rusbult (1985), respectively 0.6 and 0.7 .

Table 1. Descriptive statistics, internal consistency reliabilities, and intercorrelations (Reliabilities in Parentheses)

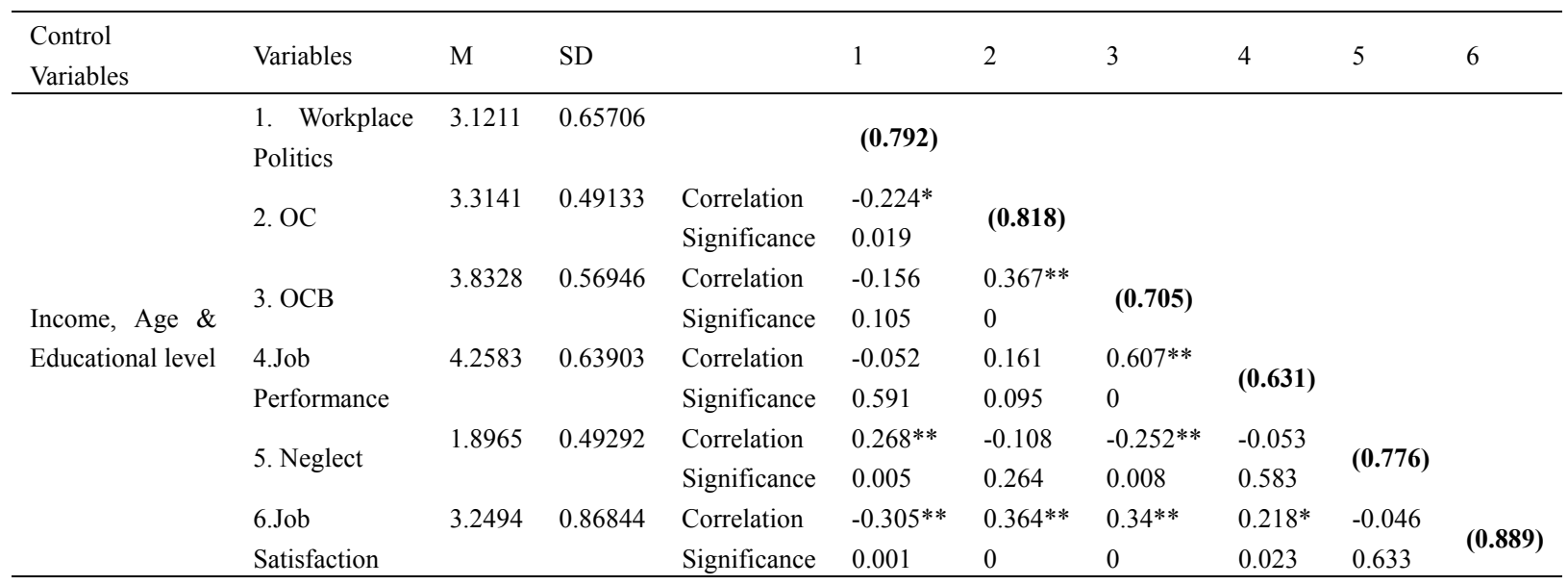

Note. $\mathrm{n}=125 ; *=$ Correlation is significant at the 0.05 level; $* *=$ Correlation is significant at the 0.01 .

\subsubsection{Organizational Citizenship Behavior}

It refers to individual behavior that is discretionary, not directly or explicitly recognized by the formal reward system, and that in the aggregate promotes the effective functioning of the organization (Organ, 1988, p. 4). William and Anderson's (1991) 12-items were used to measure this construct. Huang and You (2011) have also resorted to this scale to measure OCB. A sample item from this scale is (1) 'I Help others who have been absent', (5) 'I take personal interests in others'. The anchors for these scales were never (1) to always (5). The coefficient alpha reliability estimate for this scale was 0.70 .

\subsubsection{Job Performance}

It was defined as the level of productivity of an individual employee, relative to his or her peers, on several job-related behaviors and outcomes (Babin \& Boles, 1998). We used a seven-item self-report performance from Williams and Anderson's (1991) scales to measure this variable. 'I adequately complete assigned duties' and 'I do not fail to perform essential duties' are among the items used in the scale. Possible responses ranged from 
never (1) to always (5). The reliability estimate for the scale was 0.631 .

\section{Research Findings}

Table 2 displayed the resulting effects of WP on the response variables when job satisfaction is discarded from the list of control variables. Results showed that WP was significantly negatively related to OCB and OC ( $\beta=$ -0.199 and -0.195 respectively, $\mathrm{p}<0.05)$ and significantly positively related to neglect $(\beta=0.184, \mathrm{p} \leq 0.05)$. The model found a negative but not significant relationship between WP and job performance $(\beta=-.153, p>0.05)$.

Table 2. Multiple hierarchical regressions for the effect of workplace politics and job satisfaction on employees' work outcomes and attitudes

\begin{tabular}{|c|c|c|c|c|c|c|c|c|c|c|c|c|}
\hline \multirow[t]{2}{*}{ Variables } & \multirow{2}{*}{$\begin{array}{l}\text { Organization } \\
\text { Behavior } \\
\beta \beta \\
\end{array}$} & \multicolumn{2}{|c|}{ Citizenship } & \multicolumn{3}{|l|}{ Neglect } & \multicolumn{3}{|c|}{ Job Performance } & \multicolumn{3}{|c|}{$\begin{array}{l}\text { Organizational } \\
\text { Commitment }\end{array}$} \\
\hline & & t .val & p.val & $\beta$ & t.val & p.val & $\mathrm{B}$ & t.val & p.val & $\beta$ & t.val & p.val \\
\hline Income & -0.146 & -1.48 & 0.141 & -0.038 & -0.372 & -0.038 & -0.071 & -0.728 & 0.468 & -0.031 & -0.319 & 0.751 \\
\hline Age & -0.263 & -2.49 & $.014^{*}$ & 0.195 & 1.762 & 0.195 & -0.311 & -2.97 & 0.004 & -0.064 & -0.609 & 0.544 \\
\hline Educational & 0.043 & 0.443 & 0.659 & 0.067 & 0.665 & 0.067 & 0.202 & 2.109 & 0.037 & -0.129 & -1.35 & 0.18 \\
\hline \multicolumn{13}{|l|}{ Level } \\
\hline Workplace & -0.199 & -2.24 & $.027 *$ & 0.184 & 1.978 & $.050^{*}$ & -0.153 & -1.74 & 0.084 & -0.195 & -2.214 & $.029 *$ \\
\hline \multicolumn{13}{|l|}{ Politics } \\
\hline $\mathrm{R}^{2}$ & 0.173 & & & 0.095 & & & 0.188 & & & 0.188 & & \\
\hline Adjusted $\mathrm{R}^{2}$ & 0.108 & & & 0.025 & & & 0.124 & & & 0.124 & & \\
\hline F (anova) & $2.676 * * *$ & & & 1.35 & & & $2.956 * *$ & & & $2.95 * *$ & & \\
\hline
\end{tabular}

Regression outputs in Table 3 showed that an increase of one unit in WP engendered a very significant decrease of $-0.366(p \leq 0.001)$ in job satisfaction after controlling the research demographic variables. This implied that higher WP was associated with decreased job satisfaction, denoting a strong negative relationship between WP and job satisfaction. The adjusted R Square revealed that $15.1 \%$ of the variance of the response variable (job satisfaction) was explained by WP and the demographic variables. Income was significantly related to job satisfaction. A positive relationship was found between the two variables $(\beta=0.197, p<0.05)$. Higher income workers tended to be more satisfied with their job.

Table 4 summarized the results of four multiple hierarchical regressions on the effect of WP on response variables when considering WP as part of the control variables and job satisfaction as main predictor. Job satisfaction was significantly related to $\mathrm{OCB}, \mathrm{OC}$ and job performance. No significant relationship was found between job satisfaction and neglect. A non-significant negative relationship was found between WP and OCB, WP and OC and WP and job performance ( $\beta=-0.08 ;-0.082$ and -0.07 respectively). The model showed a significant positive relationship between WP and neglect $(\beta=0.217 ; \mathrm{p} \leq 0.05)$. The presence of job satisfaction in the model did not reduce the negative effect of WP on neglect.

Table 3. Multiple linear regressions on the relationships between workplace politics and job satisfaction

\begin{tabular}{lllll}
\cline { 2 - 4 } Variables & Job & \multicolumn{2}{l}{ Satisfaction } \\
\cline { 2 - 5 } & & $\mathrm{B}$ & t.val & p.val \\
\hline Income & 0.197 & 2.055 & $*$ \\
Age & -0.159 & -1.538 & 0.127 \\
Educational Level & -0.051 & -0.541 & 0.589 \\
Workplace Politics & -0.366 & -4.224 & $* * *$ \\
$\mathrm{R}^{2}$ & 0.212 & & \\
Adjusted R $^{2}$ & 0.151 & & \\
F (Anova) & $3.44^{* * *}$ & & \\
\hline
\end{tabular}

Note. $\mathrm{n}=125 ; * * *=\mathrm{p} \leq 0.001$.

The ANOVA values were all significant except that of neglect. The significant $\mathrm{F}$ demonstrated that the overall model linear relationship was appropriate and at the same time indicated perfect fit. The Significant F revealed 
the existence of a statistically significant relationship between the response variables and the predictors. In comparing Table 2 and 4, we noticed that WP had a more devastating effect on employees OCB, OC, and job performance in the absence of job satisfaction. WP was significantly related to neglect in the absence and presence of job satisfaction.

\section{Discussion}

\subsection{Summary}

Our objective was to investigate a potential arbitrating role of job satisfaction in the relationships between WP and employees' work outcomes and attitudes. For this purpose, we ran three regressions. In the first regression (Table 2), WP was entered as predictor and the demographic variables were controlled. Then the response variables except job satisfaction were entered simultaneously. The aim was to have WP significantly related to the response variables. The results of this regression showed that $\mathrm{OP}$ was significantly related to all variables except job performance. In the second regression (Table 3), WP was entered as predictor then the demographic variables were controlled, and job satisfaction was entered as response variable. The objective was to have job satisfaction significantly related to WP. The findings of this regression revealed a significant negative relationship between WP and job satisfaction. The final regression (Table 4) consisted of entering job satisfaction as the predictor, while considering WP as part of the control variables along with the demographic variables. The aim was to have job satisfaction significantly related to the response variables. The outputs of this last regression found that job satisfaction were significantly related to $\mathrm{OCB}, \mathrm{OC}$, and job performance and not significantly related to neglect. The regression also found that WP still had a negative effect on OC, OCB, and job performance but the relationships were not significant. WP was still positively and significantly related to neglect $(\beta=0.217, \mathrm{p} \leq 0.05)$. So, the presence of job satisfaction in the model did not affect the relationships between WP and neglect.

Table 4. Multiple hierarchical regressions for the effect of workplace politics on employees' work outcomes and attitudes

\begin{tabular}{|c|c|c|c|c|c|c|c|c|c|c|c|c|}
\hline \multirow[t]{3}{*}{ Variables } & \multirow{2}{*}{\multicolumn{3}{|c|}{$\begin{array}{l}\text { OCB } \\
\text { Step3 }\end{array}$}} & \multicolumn{4}{|c|}{ Job Performance } & \multicolumn{2}{|l|}{$\mathrm{OC}$} & \multicolumn{3}{|l|}{ Neglect } \\
\hline & & & & \multicolumn{3}{|l|}{ Step3 } & \multicolumn{3}{|l|}{ Step3 } & \multicolumn{3}{|l|}{ Step3 } \\
\hline & $\beta$ & t.val & p.val & $\beta$ & t.val & p.val & $\beta$ & t.val & p.val & $\beta$ & t.val & p.val \\
\hline Income & -0.21 & -2.202 & 0.03 & -0.116 & -1.192 & 0.236 & -0.091 & -0.963 & 0.337 & -0.056 & -0.537 & 0.592 \\
\hline Age & -0.211 & -2.078 & 0.04 & -0.275 & -2.655 & $* *$ & -0.015 & -0.149 & 0.882 & 0.209 & 1.873 & 0.064 \\
\hline Educational Level & 0.059 & 0.644 & 0.521 & 0.213 & 2.276 & $*$ & -0.113 & -1.237 & 0.218 & 0.072 & 0.71 & 0.479 \\
\hline Job satisfaction & 0.325 & 3.573 & $* * *$ & 0.227 & 2.453 & $*$ & 0.307 & 3.382 & $* * *$ & 0.091 & 0.914 & 0.363 \\
\hline \multicolumn{13}{|l|}{ Workplace } \\
\hline Politics & -0.08 & -0.877 & 0.382 & -0.07 & -0.759 & 0.45 & -0.082 & -0.912 & 0.364 & 0.217 & 2.174 & $*$ \\
\hline $\mathrm{R}^{2}$ & 0.256 & & & 0.229 & & & 0.262 & & & 0.102 & & \\
\hline Adjusted $\mathrm{R}^{2}$ & 0.191 & & & 0.161 & & & 0.095 & & & 0.023 & & \\
\hline $\mathrm{F}$ (Anova) & $3.931 * * *$ & & & $3.378 * * *$ & & & $4.040 * * *$ & & & 1.297 & & \\
\hline
\end{tabular}

Note. $\mathrm{n}=125 ; *=\mathrm{p} \leq 0.05 ; * *=\mathrm{p} \leq 0.01 ; * * *=\mathrm{p} \leq 0.001 ; \mathrm{OCB}=$ Organization Citizenship Behavior; OC=Organization Commitment.

\subsection{Conclusion}

The evidences from these three regressions revealed that job satisfaction was mediating the relationship between WP and OC and WP and OCB, that it played a minor mediating role in the relationship between WP and job performance and that it had no mediating effect in the relationship between WP and neglect.

The question is why should we care about the role of job satisfaction in the relationship between WP and employees work outcomes and attitudes? Evidences here highlighted the importance of job satisfaction in political organizations. While adding a significant contribution to the field of organizational behavior, the findings posited that special attention should be paid to job satisfaction and positioned it as a major aspect to regulate, determine and predict employees' work outcomes, attitudes or behaviors. It can be said that our data supported that an employee satisfied with his or her job can withstand the negative effects of WP on his or her work outcomes or attitudes. With the exception of neglect, reactions of employees to WP in organizations in Senegal were stronger in the absence of job satisfaction. WP had minor devastating effects on OCB, OC and job performance when employees were satisfied. In highly political organizations, managers should improve employee job satisfaction as it may reduce the negative impacts of WP on employees' work outcomes and attitudes. A potential explanation is that job satisfaction is associated with good feelings or an affective 
orientation (Price, 2001) an employee has or expects from her or his job. These pleasant aspects can dilute the adverse effects of WP on employees work outcomes and attitudes. An important aspect of higher job satisfaction is its association with desirable outcomes (Ghazzawi, 2008). As WP is endemic in organizations, raising employees' job satisfaction may help reduce employees' negative reactions to WP.

An important finding which needs special attention was the relationship between WP and neglect. Job satisfaction did not have any impact on the relationship between WP and neglect. Even satisfied, employees reported higher negligent behavior in organizations in Senegal. So WP had the same negative effect on neglect when employees were satisfied or dissatisfied with their job. Employees in organizations in Senegal reacted to WP through passive but destructive behaviors. As finding an alternative job in Senegal is sometimes difficult, employees may not choose to react to WP through destructive and active behaviors such as exit. Instead employees may react to the political environment by indulging in negligent behaviors such as when an employee exhibits reduced interest or effort, increased lateness or absenteeism, increased errors, or uses company time for personal business and so on and so forth. Such behaviors do not compromise their job, but they are very dysfunctional and costly to their organizations.

\subsection{Implications and Recommendations}

In addition to the empirical contributions, this study has managerial implications. In highly political environment, we suggest managers to undertake periodic satisfaction surveys covering all employees to gauge employee level of job satisfaction. This will enable managers to take suitable and prompt corrective actions to reduce job dissatisfaction. Nevertheless, the issue of satisfaction must not replace efforts to eradicate the causes of WP. Instead, It should be a complementary alternative to consider to reduce the adverse effects of workplace politics on employees work outcomes and attitudes.

In the case of organizations in Senegal, raising employees' job satisfaction will be possible by increasing their income. Yang, Miao, Zhu, Sun, Liu and Wu (2008) found pay as an important factor influencing overall job satisfaction. This study showed that employees in Senegal tended to overlook the political environment when they have higher income. A significant positive relationship was found between income and job satisfaction ( $\beta=$ $0.197, \mathrm{p}<0.05)$. One of the important elements of employees' work is the amount of money they earn from their job (Brickly, Smith, \& Zimmerman, 2009, p. 35).

\subsection{Limitations}

It is also important to point out some of the limitations of this research. The response rate was low. The research covered only a small sample size of respondents even though it was carried out in a four month-period. Most targeted participants were reluctant to fill out the questionnaires. This was due to the fact that some of the questions were sensitive and employees feared to fill them out. Additionally, cultural, social and religious beliefs and practices in Senegal may prevent people from revealing some of their work and personal information. In this perspective, the sample size and accuracy of the information collected may have some implications on the overall significance of the findings.

\subsection{Areas for Further Research}

Many organizations in Senegal have gone bankrupt during the last two decades. A good topic may be to explore the existence of a possible link between WP and organization bankruptcy or failure. Research similar to this one can be also replicated using a long time span and targeting workers in places other than their office may be an alternative option to reach more participants and collect more accurate information.

\section{Acknowledgments}

The authors would like to thank Martin Tshishimbi, Kemo Badiane and Carol Wei whose help and support have been tremendous in conducting this research. We would also like to express our appreciation and deepest gratitude to China Scholarship Council and Beijing Jiaotong University Office of International Students for providing an ideal and supportive environment.

\section{References}

Allen, A., \& Meyer, J. (1990). The measurements and antecedents of affective, continuance and normative commitment to the organization. Journal of Occupational Psychology, 63, 1-18. http://dx.doi.org/10.1111/j.2044-8325.1990.tb00506.x

Atak, M., \& Erturgut, R. (2010). An empirical analysis on the relation between learning organization and organizational commitment. Procedia-Social and Behavioral Sciences, 2(2), 3472-3476. http://dx.doi.org/10.1016/j.sbspro.2010.03.537 
Babin, B. J., \& Boles, J. S. (1996). The effects of perceived co-worker involvement and supervisor support on service provider role stress, performance, and job satisfaction. Journal of Retailing, 72, 57-77. http://dx.doi.org/10.1016/S0022-4359(96)90005-6

Baron, R. M., \& Kenny, D. A. (1986). The moderator-mediator variable distinction in socialcpsychological research: Conceptual, strategic, and statistical considerations. Journal of Personality and Social Psychology, 6, 1173-1182. http://dx.doi.org/10.1037/0022-3514.51.6.1173

Brickly, J., Smith, C., \& Zimmerman, J. (2009). Managerial economics and organizational architecture (5th ed.). New York, NY: Mc Graw-Hill Irvin.

Buchanan, D. (2008). You stab my back, I'll stab yours: management experience and perceptions of organization

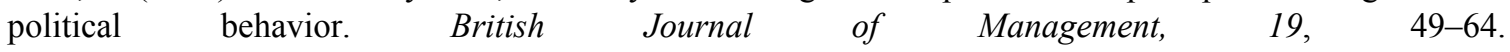
http://dx.doi.org/10.1111/j.1467-8551.2007.00533.x

Cheng, Y., \& Stockdale, M. S. (2001). The validity of the three-component model of organizational commitment in a Chinese context. Journal of Vocational Behavior, 62, 465-489. http://dx.doi.org/10.1016/S0001-8791(02)00063-5

Cronin, J. J., Brady, M. K., \& Hult, G. T. M. (2000). Assessing the effects of quality, value, and customer satisfaction on consumer behavioral intentions in service environments. Journal of Retailing, 76(2), 193-218. http://dx.doi.org/10.1016/S0022-4359(00)00028-2

Dizgah, M. R., Chegini, M. G., \& Bisokhan, R. (2012). Relationship between job satisfaction and employee job performance in Guilan Public Sector. Journal of Basic and Applied Scientific Research, 2(2), 1735-174.

Farrell, D., \& Rusbult, C. E. (1985). Understanding the retention function: A model of the causes of exit, voice, loyalty, and neglect behaviors. Personnel Administrator, 30, 129-140. http://dx.doi.org/10.1007/BF01385048

Farrell, D., \& Rusbult, C. E. (1992). Exploring the exit, voice, loyalty and neglect typology: The influence of job satisfaction, quality of alternatives, and investment size. Special Issue: Research on Hirschman's exit, voice, and loyalty model. Employee Responsibilities and Rights Journal, 5, 201-218.

Ferris, G. R., \& Hochwarter, W. A. (2011). Organizational politics. In S. Zedeck (Ed.), APA handbook of industrial and organizational psychology (pp. 435-459). Washington, USA: American Psychological Association.

Ferris, G. R., Treadway, D. C., Kolodinsky, R. W., Hochwarter, W. A., Kacmar, C. J., Douglas, C., \& Frink, D. D. (2005). Development and validation of the political skill inventory. Journal of Management, 31, 126-152. http://dx.doi.org/10.1177/0149206304271386

Frost, P. J. (1987). Power, politics, and influence. In F. M. Jablin, L. L. Putname, K. H. Roberts \& L. W. Porter (Eds.), Handbook of organizational Communication (pp. 503-548). Newbury Park, CA: Sage Publications.

Gbadamosi, L., \& Chinaka, N. J. (2011). Organizational politics, turnover intention and organizational commitment as predictors of employees' efficiency and effectiveness in academia. Proceedings of Informing Science \& IT Education Conference.

Ghazzawi, I. (2008). Job satisfaction antecedents and consequences: a new conceptual framework and research agenda. The Business Review, 11, 1-11.

Haq, I. U. (2011). The impact of interpersonal conflict on job outcomes: Mediating role of perception of organizational politics. Procedia-Social and Behavioral Sciences, 25, 287-310. http://dx.doi.org/10.1016/j.sbspro.2011.10.549

Harris, R. B., \& Harris, J. K. (2007). A test of competing models of the relationship among perceptions of organizational politics, perceived organizational support, and individual outcomes. Journal of Social Psychology, 147(6), 631-655. http://dx.doi.org/10.3200/SOCP.147.6.631-656

Hisrchman, A. (1970). Exit, voice, and loyalty: Responses to decline in firms, organizations, and states. Cambrigde, MA: Haward University Press.

Huang, C. C., \& You, C. S. (2011). The three components of organizational commitment on in-role behaviors and organizational citizenship behaviors. African Journal of Business Management, 5(28), 11335-11344.

James, L. R., \& Brett, J. M. (1984). Mediators, moderators, and tests for mediation. Journal of Applied Psychology, 69, 307-321. http://dx.doi.org/10.1037/0021-9010.69.2.307 
Kacmar, K. M., \& Carlson, D. S. (1997). Further validation of the perceptions of politics scale (POPS): A multiple sample investigation. Journal of Management, 23(5), 627-658. http://dx.doi.org/10.1177/014920639702300502

Karatepe, O. M., Babakus, E., \& Yavas, Y. (2012). Affectivity and organizational politics and antecedents of burnout among frontline hotel employees. International Journal of Hospitality Management, 31, 66-75. http://dx.doi.org/10.1016/j.ijhm.2011.04.003

Kaya, E. (1995). Job satisfaction of the librarians in the developing countries. 61st IFLA General Conference.

Leck, J. D., \& Saunders, D. M. (1992). Hirschman's loyalty: Attitude or behavior? Employee Responsibilities and Rights Journal, 5, 219-229. http://dx.doi.org/10.1007/BF01385049

Meyer, J. P., Becker, T. E., \& Van Dick, R. (2006). Social identities and commitment at work: Toward an integrative model. Journal of Orgazational Behavior, 27, 665-683. http://dx.doi.org/10.1002/job.383

Meyer, J. P., Stanley, D. J., Herscovitch, L., \& Topolnytsky, L. (2002). Affective, continuance, and normative commitment to the organization: A Meta-analysis of antecedents, correlates, and consequences. Journal of Vocational Behavior, 61, 20-52. http://dx.doi.org/10.1006/jvbe.2001.1842

Miller, B. K, Rutherford, M. A., \& Kolodinsky, R. W. (2008). Perceptions of organizational politics: A meta-analysis of outcomes. Journal of Business Psychology, 22, 209-222. http://dx.doi.org/10.1007/s10869-008-9061-5

Miller, B. K., Byrne, Z. S., Rutherford, M. A., \& Hansen, A. M. (2009). Perceptions of organizational politics: A demonstration of the reliability generalization technique. Journal of Managerial Issues, 21, 280-300.

Organ, D. W. (1988). Organizational citizenship behavior: The good soldier syndrome. Lexington, MA: Lexington Books.

Parker, C. P., Dipboye, R. L., \& Jackson, S. L. (1995). Perceptions of organizational politics: An investigation of antecedents and consequences. Journal of Management, 21(5), 891-912. http://dx.doi.org/10.1177/014920639502100505

Podsakoff, N. P., LePine, J. A., \& LePine, M. A. (2007). Differential Challenge Stressor-Hindrance Stressor Relationships with Job Attitudes, Turnover Intentions, Turnover, and Withdrawal Behavior: A Meta-Analysis. Journal of Applied Psychology, 92, 438-454. http://dx.doi.org/10.1037/0021-9010.92.2.438

Podsakoff, P., MacKenzie, S., Paine, J., \& Bachrach, D. (2000). Organizational citizenship behaviors: A critical review of the theoretical and empirical literature and suggestions for future research. Journal of Management, 26, 513-563. http://dx.doi.org/10.1177/014920630002600307

Price, J. L. (2001). Reflections on the determinants of voluntary turnover. International Journal of Manpower, 22(7), 600-624. http://dx.doi.org/10.1108/EUM0000000006233

Randall, M. L., Cropanzano, R., Bormann, C. A., \& Birjulin, A. (1999). Organizational politics and organizational support as predictors of work attitudes, job performance and organizational citizenship behavior. Journal of Organizational Behavior, 20(2), $159-174$. http://dx.doi.org/10.1002/(SICI)1099-1379(199903)20:2<159::AID-JOB881>3.0.CO;2-7

Robbins, S. P. (2000). Essentials of Organizational Behavior (6th ed.). http://dx.doi.org/10.1002/1099-1379(200008)21:5<525::AID-JOB40>3.0.CO;2-T

Robbins, S. P. (2001). Organizational behavior (9th ed.). Upper Saddle River, NJ: Prentice Hall International Inc.

Rosen, C. C., Levy, P. E., \& Hall, R. J. (2006). Placing perceptions of politics in the context of the feedback environment, employee attitudes, and job performance. Journal of Applied Psychology, 91, 211-220. http://dx.doi.org/10.1037/0021-9010.91.1.211

Rosse, J., \& Saturay, L. (2004). Individual differences in adaptation to work dissatisfaction (Presented at the 2004 Meeting of the Western Academy of Management, April 1-4, Anchorage, Alaska). Retrieved from http://leeds-faculty.colorado.edu/Rosse/Research/WAM04\%20presentation.pdf

Schriesheim, C., \& Tsui, A. S. (1980). Development and validation of a short satisfaction instrument for use in survey feedback interventions. Paper presented at the Western Academy of Management Meeting.

Valle, M., \& Perrewe, P. L. (2000). Do politics perceptions relate to political behaviors? Tests of an implicit assumption and expanded model. Human Relations, 53, 359-386. http://dx.doi.org/10.1177/0018726700533004 
Valle, M., \& Witt, L. A. (2001). The moderating effect of teamwork perceptions on the prganizational politics-job satisfaction relationship. Journal of Social Psychology, 141(3), 379-388. http://dx.doi.org/10.1080/00224540109600559

Vigoda, E. G. (2000). Organizational politics, job attitudes, and work outcomes: Exploration and implications for the public sector. Journal of Vocational Behavior, 57, 326-347. http://dx.doi.org/10.1006/jvbe.1999.1742

Vigoda, E. G., \& Cohen, A. (2002). Influence tactics and perceptions of organizational politics: A longitudinal study. Journal of Business Research, 55, 311-324. http://dx.doi.org/10.1016/S0148-2963(00)00134-X

Williams, L. J., \& Anderson, S. E. (1991). Job satisfaction and organizational commitment as predictors of organizational citizenship and in-role behaviors. Journal of Management, 17, 601-617. http://dx.doi.org/10.1177/014920639101700305

Yang, H., Miao, D., Zhu, X., Sun, Y., Liu, X., \& Wu, S. (2008). The influence of a pay increase on job satisfaction: A study with the Chinese army. Social Behavior and Personality, 36(10), 1333-1340. http://dx.doi.org/10.2224/sbp.2008.36.10.1333

Yen, W. W., Chen, S. C., \& Yen, S. I. (2009). The impact of perceptions of organizational politics on workplace friendship. African Journal of Business Management, 3(10), 548-554.

\section{Copyrights}

Copyright for this article is retained by the author(s), with first publication rights granted to the journal.

This is an open-access article distributed under the terms and conditions of the Creative Commons Attribution license (http://creativecommons.org/licenses/by/3.0/). 